\title{
CRYSTAL STRUCTURES AND CHARACTERIZATION OF TWO RARE-EARTH-GLUTARATE COORDINATION NETWORKS: ONE-DIMENSIONAL $\left[\mathrm{Nd}\left(\mathrm{C}_{5} \mathrm{H}_{6} \mathrm{O}_{4}\right)\left(\mathrm{H}_{2} \mathrm{O}\right)_{4}\right] \cdot \mathrm{Cl}$ AND THREE-DIMENSIONAL $\left[\operatorname{Pr}\left(\mathrm{C}_{5} \mathrm{H}_{6} \mathrm{O}_{4}\right)\left(\mathrm{C}_{5} \mathrm{H}_{7} \mathrm{O}_{4}\right)\left(\mathrm{H}_{2} \mathrm{O}\right)\right] \cdot \mathrm{H}_{2} \mathrm{O}$
}

\author{
S. Hussain ${ }^{1}$, I.U. Khan ${ }^{1}$, W.T.A. Harrison ${ }^{2}$, M.N. Tahir ${ }^{3}$ \\ ${ }^{1}$ Department of Chemistry, Government College University, Lahore, Pakistan \\ E-mail: sajjaduet07@yahoo.com \\ ${ }^{2}$ Department of Chemistry, University of Aberdeen, Aberdeen, Scotland \\ E-mail: w.harrison@abdn.ac.uk \\ ${ }^{3}$ Department of Physics, University of Sargodha, Sargodha, Pakistan
}

Received December, 09, 2013

\begin{abstract}
The synthesis, crystal structures, and characterization (IR, TGA/DSC) of $\left[\mathrm{Nd}\left(\mathrm{C}_{5} \mathrm{H}_{6} \mathrm{O}_{4}\right)\right.$. $\left.\cdot\left(\mathrm{H}_{2} \mathrm{O}\right)_{4}\right] \cdot \mathrm{Cl}(\mathbf{1})$ and $\left.\operatorname{Pr}\left(\mathrm{C}_{5} \mathrm{H}_{6} \mathrm{O}_{4}\right)\left(\mathrm{C}_{5} \mathrm{H}_{7} \mathrm{O}_{4}\right)\left(\mathrm{H}_{2} \mathrm{O}\right)\right] \cdot \mathrm{H}_{2} \mathrm{O}(2)$ are described. Compound $\mathbf{1}$ is a onedimensional coordination polymer containing double chains incorporating pairs of edgesharing $\mathrm{NdO}_{9}$ polyhedra linked by glutarate dianions. A network of $\mathrm{O}-\mathrm{H} \cdots \mathrm{O}$ and $\mathrm{O}-\mathrm{H} \cdots \mathrm{Cl}$ hydrogen bonds helps to consolidate the structure. Compound $\mathbf{2}$ is a three-dimensional coordination polymer incorporating chains of edge-sharing $\mathrm{PrO}_{10}$ polyhedra. Its glutarate ion adopts an extended conformation, whereas its hydrogen glutarate ion takes on a twisted conformation. $\mathrm{O}-\mathrm{H} \cdots \mathrm{O}$ hydrogen bonds are seen in the crystal structure, which features small channels occupied by water molecules. Crystal data: $1, \mathrm{C}_{5} \mathrm{H}_{14} \mathrm{ClNdO}_{8}, M_{\mathrm{r}}=381.85$, monoclinic, $P 2_{1} / c$ (No. 14), $a=8.9763(6) \AA, \quad b=15.9277(11) \AA, \quad c=8.8690(6) \AA, \quad \beta=112.090(2)^{\circ}$, $V=1174.94(14) \AA^{3}, Z=4, R(F)=0.016, w R\left(F^{2}\right)=0.037 . \quad 2, \mathrm{C}_{10} \mathrm{H}_{17} \mathrm{O}_{10} \mathrm{Pr}, M_{\mathrm{r}}=438.15$, orthorhombic, Pbca (No. 61), $a=16.3030(7) \AA, \quad b=8.6714(4) \AA, \quad c=19.3899(8) \AA$, $V=2741.1(2) \AA^{3}, Z=8, R(F)=0.020, w R\left(F^{2}\right)=0.050$.
\end{abstract}

DOI: $10.15372 / J S C 20150516$

K e y w o r d s: synthesis, crystal structure, coordination polymer, neodymium, praseodymium.

\section{INTRODUCTION}

Glutaric acid $\mathrm{HO}_{2} \mathrm{C}\left(\mathrm{CH}_{2}\right)_{3} \mathrm{CO}_{2} \mathrm{H}\left(\mathrm{H}_{2}\right.$ glut or $\left.\mathrm{C}_{5} \mathrm{H}_{8} \mathrm{O}_{4}\right)$ has applications in polymer chemistry [1] and can form liquid crystals [2]. In its doubly-deprotonated form $\left(\mathrm{glu}^{2-}\right)$, it is a versatile bridging ligand with a flexible backbone and many coordination polymers have been reported in combination with both transition metal and rare-earth cations [ $3-8$ ].

In this paper, as an extension of these studies, we describe the syntheses, characterizations, and single crystal structures of two rare-earth glutarate networks: $\left[\mathrm{Nd}\left(\mathrm{C}_{5} \mathrm{H}_{6} \mathrm{O}_{4}\right)\left(\mathrm{H}_{2} \mathrm{O}\right)_{4}\right] \cdot \mathrm{Cl}$ (1) and $\left[\operatorname{Pr}\left(\mathrm{C}_{5} \mathrm{H}_{6} \mathrm{O}_{4}\right)\left(\mathrm{C}_{5} \mathrm{H}_{7} \mathrm{O}_{4}\right)\left(\mathrm{H}_{2} \mathrm{O}\right)\right] \cdot \mathrm{H}_{2} \mathrm{O}(\mathbf{2})$.

\section{MATERIALS AND METHODS}

Synthesis of $1.0 .500 \mathrm{mmol}(0.179 \mathrm{~g})$ of $\mathrm{NdCl}_{3} \cdot 6 \mathrm{H}_{2} \mathrm{O}$ was dissolved in $10 \mathrm{ml}$ distilled water and $2.00 \mathrm{mmol}(0.264 \mathrm{~g})$ of glutaric acid was dissolved in $15 \mathrm{ml}$ ethanol. Five drops of a $1 \mathrm{~N} \mathrm{NaOH}$ solution was added to raise the $\mathrm{pH}$ of the glutaric acid solution. The solutions were mixed and stirred for 
$1 \mathrm{~h}$ at room temperature. The mixture was filtered and kept at room temperature for crystallization. After 10 days, pink blocks of 1 were recovered in $43 \%$ yield by filtration and rinsing with ethanol. Anal. calc. (\%) for $\mathrm{C}_{5} \mathrm{H}_{15} \mathrm{O}_{10} \mathrm{NdCl}$ : C 14.57, $\mathrm{H} 3.63$; found: $\mathrm{C} 15.02, \mathrm{H} 3.74$.

Synthesis of $2.0 .500 \mathrm{mmol}(0.187 \mathrm{~g})$ of $\mathrm{PrCl}_{3} \cdot 6 \mathrm{H}_{2} \mathrm{O}$ was dissolved in $10 \mathrm{ml}$ distilled water and $2.00 \mathrm{mmol}(0.264 \mathrm{~g})$ of glutaric acid was dissolved in $15 \mathrm{ml}$ ethanol. Eight drops of a $1 \mathrm{~N} \mathrm{NaOH}$ solution was added to raise the $\mathrm{pH}$ of the glutaric acid solution. The solutions were mixed and stirred for $1 \mathrm{~h}$ at room temperature. The mixture was filtered and kept at room temperature for crystallization. After 10 days, light green needles of $\mathbf{2}$ were recovered by vacuum filtration and rinsing with ethanol (yield $=48 \%$ ). Anal. calc. (\%) for $\mathrm{C}_{10} \mathrm{H}_{16} \mathrm{O}_{10} \mathrm{Pr}$ : C 27.47, H 3.68; found: C 28.12, H 3.85.

Physical measurements. The IR spectra of $\mathbf{1}$ and $\mathbf{2}$ were recorded on a Perkin-Elmer FTIR 180 spectrophotometer using $\mathrm{KBr}$ pellets over the frequency range $4000-400 \mathrm{~cm}^{-1}$. Elemental analyses for $\mathrm{C}, \mathrm{H}$, and $\mathrm{N}$ were performed on a Varian Micro-Cube Analyzer. Thermal analyses $\left(25-1200^{\circ} \mathrm{C}\right)$ were recorded under a continuous $\mathrm{N}_{2}$ flow with a ramp rate of $10^{\circ} \mathrm{C} \cdot \mathrm{min}^{-1}$ using a DSC/TGA model SDT Q 600, TA Instruments, USA. Alumina crucibles were used for recording the TG-DSC curves.

Crystal structure determinations. Intensity data for 1 (pale pink block, $0.32 \times 0.15 \times 0.14 \mathrm{~mm}$ ) and 2 (pale green needle, $0.30 \times 0.05 \times 0.05 \mathrm{~mm}$ ) were collected at room temperature using a Bruker Apex II CCD diffractometer (MoK $K_{\alpha}$ radiation, $\lambda=0.71073 \AA$ ). Multi-scan absorption corrections (transmission-factor ranges for $\mathbf{1}$ and $\mathbf{2}=0.317-0.561$ and $0.411-0.840$ respectively) were made with SADABS [ 9 ] during data reduction. The structures were routinely solved by direct methods with SHELXS-97 [ 7 ] in space group $P 2_{1} / c$ for $\mathbf{1}$ and $P b c a$ for $\mathbf{2}$ and the structural models were developed and refined against $|F|^{2}$ using SHELXL-97 [ 10 ]. For both structures, the C-bound $\mathrm{H}$ atoms were geometrically placed $(\mathrm{C}-\mathrm{H}=0.97 \AA)$ and refined as riding atoms. The water $\mathrm{H}$ atoms were located in difference maps and refined as riding atoms in their as-found relative positions. The carboxylic acid $\mathrm{H}$ atom in $\mathbf{2}$ was located in a different map and its position freely was refined. The constraint $U_{\text {iso }}(\mathrm{H})=1.2 U_{\text {eq }}$ (carrier) was applied in all cases. Molecular graphics were generated with ORTEP-3 [11 ] and ATOMS [ 12 ]. Crystal data for $\mathbf{1}$ and $\mathbf{2}$ are summarized in Table 1 and full details are available as supplementary material (CIF format).

Crystallographic and data collection parameters

\begin{tabular}{l|c|c}
\hline \multicolumn{1}{c|}{ Parameters } & $\mathbf{1}$ & $\mathbf{2}$ \\
\hline Empirical formula & $\mathrm{C}_{5} \mathrm{H}_{14} \mathrm{ClNdO}_{8}$ & $\mathrm{C}_{10} \mathrm{H}_{17} \mathrm{O}_{10} \mathrm{Pr}$ \\
Formula weight & 381.85 & 438.15 \\
Crystal system & Monoclinic & Orthorhombic \\
Space group & $P 2_{1} / c(\mathrm{No} .14)$ & Pbca $($ No. 61$)$ \\
$a, b, c, \AA$ & $15.927(11), 8.8690(6)$ & $16.3030(7), 8.6714(4), 19.3899(8)$ \\
$\beta$, deg. & $112.090(2)$ & 90 \\
$V, \AA^{3}$ & $1174.94(14)$ & $2741.1(2)$ \\
$Z$ & 4 & 8 \\
$\rho_{\text {calc }}, \mathrm{g} / \mathrm{cm}^{3}$ & 2.159 & 2.123 \\
$\mu, \mathrm{mm}^{-1}$ & 4.666 & 3.605 \\
Data scanned & 10837 & 21847 \\
Unique data & 2902 & 3409 \\
$R_{\text {Int }}$ & 0.025 & 0.030 \\
$R(F)$ & 0.016 & 0.020 \\
$w R\left(F^{2}\right)$ & 0.037 & 0.050 \\
Min, max $\Delta \rho, \mathrm{e} / \AA^{3}$ & $-0.65,+0.75$ & $-0.91,+0.71$
\end{tabular}




\section{RESULTS}

Infrared spectra. The IR spectrum of 1 shows strong, sharp bands at $1640 \mathrm{~cm}^{-1}, 1528 \mathrm{~cm}^{-1}$, and $1437 \mathrm{~cm}^{-1}$, which we attribute to the bridging symmetric, bidentate symmetric, and asymmetric stretching vibrations of the carboxylate group respectively [13]. These assignments are consistent with the different bonding modes of the glutarate ion in the crystal structure of $\mathbf{1}$ (vide infra). The $\mathrm{C}=\mathrm{O}$ stretch in free glutaric acid occurs at $1699 \mathrm{~cm}^{-1}$. A strong, very broad band centered around $3350 \mathrm{~cm}^{-1}$ in 1 corresponds to the $\mathrm{O}-\mathrm{H}$ vibrations of hydrogen bonded water molecules and a cluster of weak, overlapped bands around $645 \mathrm{~cm}^{-1}$ can be tentatively assigned to $\mathrm{Nd}-\mathrm{O}$ bond vibrations [ 14 ].

The corresponding carboxylate peaks for 2 occur at $1661 \mathrm{~cm}^{-1}, 1530 \mathrm{~cm}^{-1}$, and $1435 \mathrm{~cm}^{-1}$ respectively. The very broad water stretch is centered around $3340 \mathrm{~cm}^{-1}$ and a group of weak, overlapping peaks corresponding to $\mathrm{Pr}-\mathrm{O}$ bond vibrations occur around $660 \mathrm{~cm}^{-1}$.

Thermal analysis. TGA for 1 showed thermal stability to about $110^{\circ} \mathrm{C}$, followed by a weight loss of $18 \%$, which was completed by $240{ }^{\circ} \mathrm{C}$. This is in good agreement with a decomposition scheme that loses the four water molecules from 1 (calc. $=19 \%$ ). The residue is stable until about $350{ }^{\circ} \mathrm{C}$, at which point it starts to lose a further $\sim 32 \%$ weight over a broad temperature range to $\sim 1200{ }^{\circ} \mathrm{C}$ (the limit of operation of the instrument). The calculated total mass loss to give a residue of "NdOCl" is $49 \%$.

TGA for 2 showed an $8 \%$ weight loss between $\sim 80{ }^{\circ} \mathrm{C}$ and $150{ }^{\circ} \mathrm{C}$ (presumed loss of all water; calc. $=8 \%$ ), a further loss of $15 \%$ between $200{ }^{\circ} \mathrm{C}$ and $350{ }^{\circ} \mathrm{C}$ (intermediate unknown) and then between $400{ }^{\circ} \mathrm{C}$ and $1200{ }^{\circ} \mathrm{C}$ (the limit of operation of the instrument), another $32 \%$ weight loss (total loss $=55 \%$ ). The calculated weight loss for 1 transforming to $1 / 2 \operatorname{Pr}_{2} \mathrm{O}_{3}$ is $63 \%$.

Crystal structure of 1 . Compound 1 is a one-dimensional coordination polymer: its asymmetric unit (Fig. 1) contains one $\mathrm{Nd}^{3+}$ ion, one doubly-deprotonated $\mathrm{C}_{5} \mathrm{H}_{6} \mathrm{O}_{4}^{2-}$ glutarate ion, a chloride ion, and four water molecules. When symmetry-generated oxygen atoms are considered, the neodymium ion is coordinated by nine $\mathrm{O}$ atoms arising from two $\mathrm{O}, \mathrm{O}$-bidentate glutarate ions, an O-monodentate glutarate ion, and four water molecules. The mean $\mathrm{Nd}-\mathrm{O}$ bond distance is $2.493 \AA$ (the next-nearest $\mathrm{O}$ atom is farther than $4.25 \AA$ distant) and the bond valence sum (BVS) [ 15] for the metal ion is $3.28 \AA$ (expected value $=3.00 \AA$ ). If it is not assumed to be irregular, its coordination geometry can be just described as an extremely distorted capped square anti-prism [16] (Fig. 2), with the square faces defined by $\mathrm{O} 2 / \mathrm{O}^{\mathrm{i}} / \mathrm{O} 5 / \mathrm{O} 6$ and $\mathrm{O} 3{ }^{\mathrm{ii}} / \mathrm{O} 4{ }^{\mathrm{ii}} / \mathrm{O} 7 / \mathrm{O} 8$ (Table 2, symmetry codes): the dihedral angle between

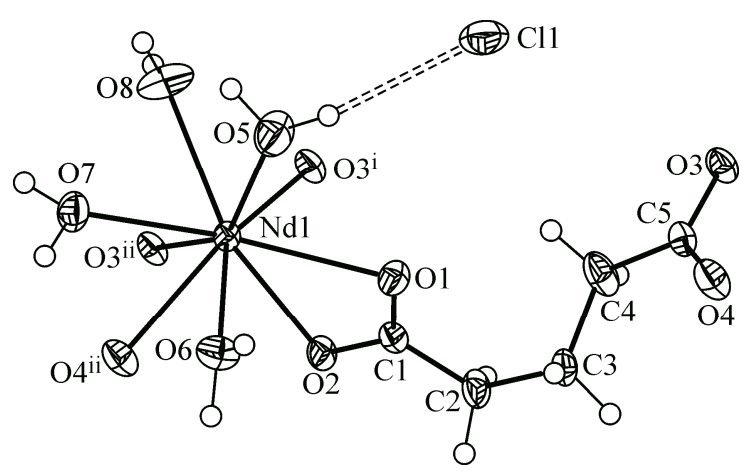

Fig. 1. Asymmetric unit of 1, with atoms added to complete the $\mathrm{Nd}$ coordination polyhedron, showing $50 \%$ displacement ellipsoids. The $\mathrm{O}-\mathrm{H} \cdots \mathrm{Cl}$ hydrogen bond is shown as a double-dashed line. Symmetry codes as in Table 2

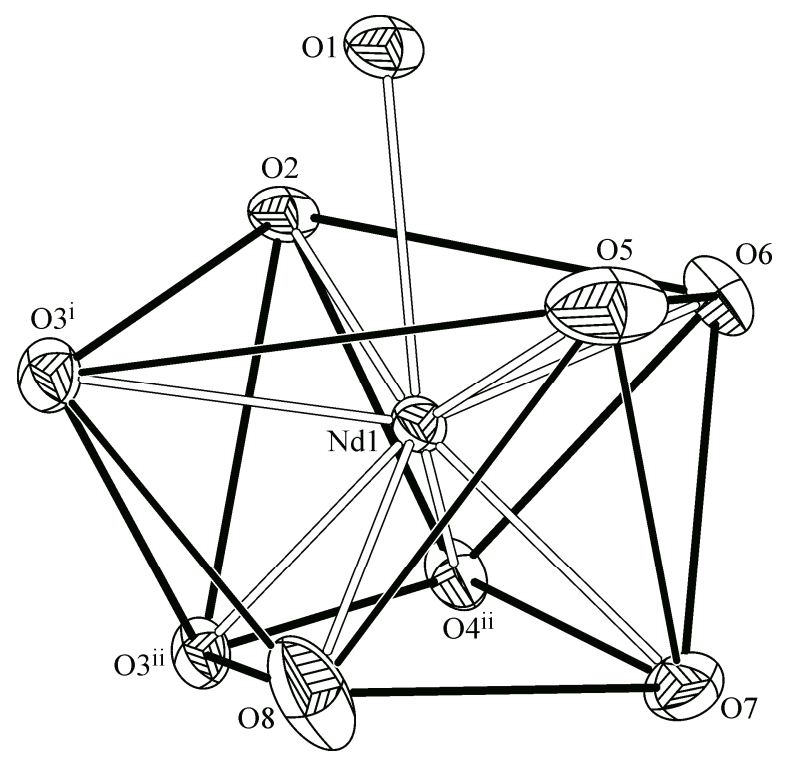

Fig. 2. Nd1 coordination polyhedron in $\mathbf{1}$. Symmetry codes as in Table 2 
Selected bond lengths $(\AA)$ and angles (deg.) for 1

\begin{tabular}{|c|c|c|c|c|c|c|}
\hline $\mathrm{Nd} 1-\mathrm{O} 6$ & $2.4433(15)$ & $\mathrm{O} 5-\mathrm{H} 5 \mathrm{~A} \cdots \mathrm{Cl}$ & 0.83 & 2.36 & $3.1909(17)$ & 172 \\
\hline $\mathrm{Nd} 1-\mathrm{O} 3^{\mathrm{i}}$ & $2.4791(15)$ & $\mathrm{O} 5-\mathrm{H} 5 \mathrm{~B} \cdots \mathrm{Cl1}{ }^{\mathrm{iii}}$ & 0.87 & 2.33 & $3.1579(18)$ & 158 \\
\hline $\mathrm{Nd} 1-\mathrm{O} 8$ & $2.4824(16)$ & $\mathrm{O} 6-\mathrm{H} 6 \mathrm{~A} \cdots \mathrm{O} 1^{\mathrm{iv}}$ & 0.84 & 1.90 & $2.733(2)$ & 172 \\
\hline $\mathrm{Nd} 1-\mathrm{O} 1$ & $2.5229(14)$ & $\mathrm{O} 6-\mathrm{H} 6 \mathrm{~B} \cdots \mathrm{Cl1}^{\mathrm{iv}}$ & 0.89 & 2.24 & $3.0930(16)$ & 162 \\
\hline $\mathrm{Nd} 1-\mathrm{O} 4^{\mathrm{ii}}$ & $2.5484(14)$ & $\mathrm{O} 7-\mathrm{H} 7 \mathrm{~A} \cdots \mathrm{O} 4^{\text {iv }}$ & 0.86 & 1.91 & $2.767(2)$ & 172 \\
\hline $\mathrm{Nd} 1-\mathrm{O} 7$ & $2.4677(15)$ & $\mathrm{O} 7-\mathrm{H} 7 \mathrm{~B} \cdots \mathrm{Cl1}^{\mathrm{ii}}$ & 0.84 & 2.36 & $3.1854(16)$ & 166 \\
\hline $\mathrm{Nd} 1-\mathrm{O} 5$ & $2.4818(16)$ & $\mathrm{O} 8-\mathrm{H} 8 \mathrm{~A} \cdots \mathrm{O} 2^{\mathrm{v}}$ & 0.81 & 1.91 & $2.679(2)$ & 158 \\
\hline $\mathrm{Nd} 1-\mathrm{O} 2$ & $2.4838(15)$ & $\mathrm{O} 8-\mathrm{H} 8 \mathrm{~B} \cdots \mathrm{C} 11^{\mathrm{iii}}$ & 0.85 & 2.31 & $3.1020(17)$ & 156 \\
\hline $\mathrm{Nd} 1-\mathrm{O} 3^{\mathrm{ii}}$ & $2.5313(15)$ & & & & & \\
\hline $\mathrm{C} 1-\mathrm{O} 1$ & $1.260(2)$ & $\mathrm{C} 1-\mathrm{C} 2-\mathrm{C} 3-\mathrm{C} 4$ & $-70.1(3)$ & & & \\
\hline $\mathrm{C} 5-\mathrm{O} 4$ & $1.249(2)$ & $\mathrm{C} 2-\mathrm{C} 3-\mathrm{C} 4-\mathrm{C} 5$ & 169.90(19) & & & \\
\hline $\mathrm{C} 1-\mathrm{O} 2$ & $1.268(2)$ & & & & & \\
\hline $\mathrm{C} 5-\mathrm{O} 3$ & $1.282(2)$ & & & & & \\
\hline
\end{tabular}

For the hydrogen bonds, the four values correspond to the $D-\mathrm{H}, \mathrm{H} \cdots A$, and $D \cdots A$ separations $(\AA)$ and the $D-\mathrm{H} \cdots A$ angle (deg), respectively.

Symmetry codes: ${ }^{\mathrm{i}} 1-x, 1-y, 1-z ;{ }^{\text {ii }} x, y, z+1 ;{ }^{\text {iii }} x, 1 / 2-y, z+1 / 2 ;{ }^{\text {iv }}-x, 1-y, 1-z ;{ }^{\mathrm{v}} 1-x$, $1-y, 2-z$.

them is $7.35(5)^{\circ}$. The faces are displaced by $-1.5556(8) \AA$ and $0.8500(8) \AA$ respectively from the metal atom, and $\mathrm{O} 1$ serves as the capping atom. It is notable that all the water $\mathrm{O}$ atoms lie on one side of the coordination sphere.

The glutarate ion in $\mathbf{1}$ is twisted: the $\mathrm{C} 1-\mathrm{C} 2-\mathrm{C} 3-\mathrm{C} 4$ fragment has a gauche conformation and the $\mathrm{C} 2-\mathrm{C} 3-\mathrm{C} 4-\mathrm{C} 5$ fragment has an anti conformation (Table 2). The dihedral angle between the $\mathrm{C} 1 / \mathrm{O} 1 / \mathrm{O} 2$ and $\mathrm{C} 5 / \mathrm{O} 3 / \mathrm{O} 4$ carboxylate groups at each end of the ion is $84.00(16)^{\circ}$.

The bonding modes of the two carboxylate groups of the glutarate ion are different: the C1/O1/O2 group is chelating bidentate to a single metal ion and the $\mathrm{C} 5 / \mathrm{O} 3 / \mathrm{O} 4$ group is bridging bidentate $\left(\mathrm{O}, \mu^{2}\right.$ $\left.\mathrm{O}^{\prime}\right)$ to two metal ions. The displacements of the chelated metal ions from the $\mathrm{C} 1$ and $\mathrm{C} 5$ carboxylate groups are $-0.119(9) \AA$ and $-0.200(9) \AA$ respectively. The $\mathrm{C}-\mathrm{O}$ bond lengths of the $\mathrm{C} 1$-containing carboxylate group are almost the same length, whereas the $\mathrm{C}-\mathrm{O}$ lengths for the $\mathrm{C} 6$ grouping are distinctly different (Table 2), with the longer $\mathrm{C} 6-\mathrm{O} 3$ bond representing the $\mu^{2}-\mathrm{O}$ atom, which is consistent with the previous results [6]. In the ligand, the terminal $\mathrm{C}-\mathrm{C}_{\mathrm{c}}(\mathrm{c}=$ carboxylate) bond lengths (mean $=1.496 \AA)$ are slightly shorter than the intermediate bond lengths (mean $=1.520 \AA$ ), which follows the trend seen in an analysis of bond lengths in the Cambridge Database [17].

These coordination modes result in [001] double chains of stoichiometry $\left[\mathrm{Nd}(\mathrm{glu})\left(\mathrm{H}_{2} \mathrm{O}\right)_{4}\right]^{+}$in the crystal of 1 (Fig. 3), in which the $\mathrm{NdO}_{9}$ polyhedra are linked by their common $\mathrm{O}_{3}{ }^{\mathrm{i}} \cdots \mathrm{O} 3{ }^{\mathrm{ii}}$ edge and the $\mathrm{Nd} 1 \cdots \mathrm{Nd} 1^{\mathrm{v}}$ separation is $4.1751(3) \AA$. Pairs of glutarate ions fuse the adjacent $\mathrm{Nd}_{2} \mathrm{O}_{16}$ units into the [001] chains which are cross-linked by $\mathrm{O}-\mathrm{H} \cdots \mathrm{O}$ hydrogen bonds (Table 2) into (010) sheets. The chloride ions in 1 occupy the regions between the (010) sheets and each one accepts five $\mathrm{O}-\mathrm{H} \cdots \mathrm{Cl}$ hydrogen bonds (Table 2) from nearby water molecules to provide structural cohesion in the [010] direction. There are no possible metal - chloride-ion interactions in 1: the shortest $\mathrm{Nd} \cdots \mathrm{Cl}$ separation is greater than $4.6 \AA$.

Crystal structure of 2. Compound $\mathbf{2}$ is a three-dimensional coordination polymer: its asymmetric unit contains one $\mathrm{Pr}^{3+}$ ion, one doubly-deprotonated $\mathrm{C}_{5} \mathrm{H}_{6} \mathrm{O}_{4}^{2-}$ glutarate $\left(\mathrm{glu}^{2-}\right.$ ) ion, one singlydeprotonated $\mathrm{C}_{5} \mathrm{H}_{7} \mathrm{O}_{4}^{-}$hydrogen glutarate ( $\mathrm{Hglu}^{-}$) ion, and two water molecules (Fig. 4). 
Fig. 3. Fragment of an [001] double chain in $\mathbf{1}$ showing the edge-shared $\mathrm{NdO}_{9}$ polyhedra

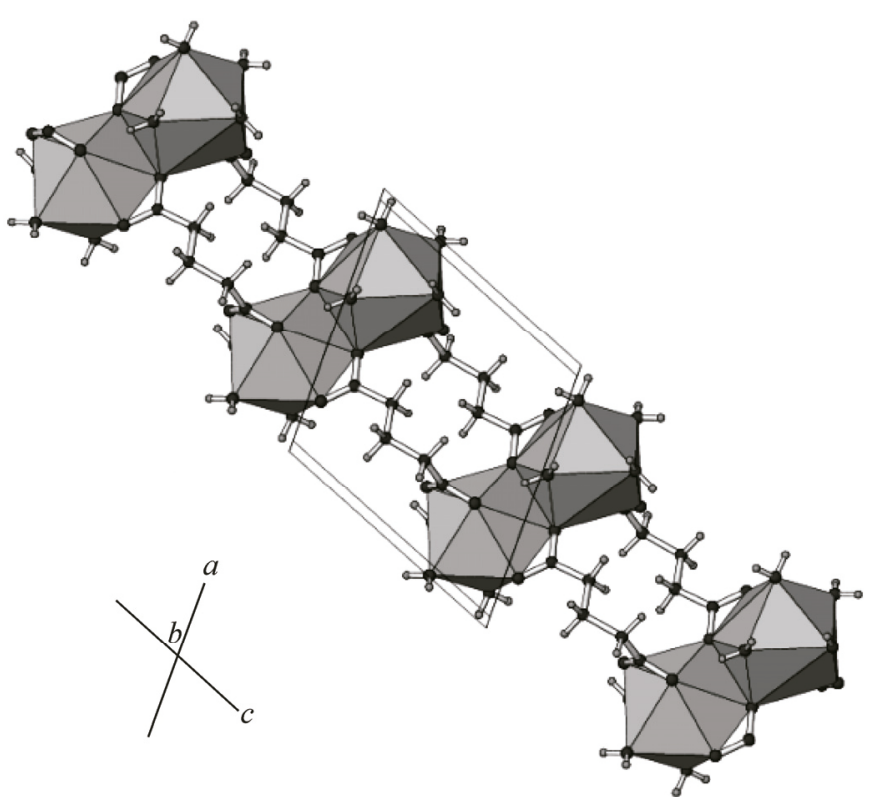

In the extended structure, the Pr1 atom is coordinated by ten oxygen atoms (Table 3 ) with a mean separation of $2.581 \AA$ and a BVS of $3.13 \AA$. These $\mathrm{O}$ atoms arise from two bidentate ligands, five monodentate ligands, and one coordinated water molecule (O9). The coordination geometry about the metal ion is well described as a bicapped square anti-prism [18 ] (Fig. 5), with $\mathrm{O} 1^{\mathrm{ii}} / \mathrm{O} 9 / \mathrm{O} 3^{\mathrm{iii}} / \mathrm{O} 7^{\mathrm{v}}$ and $\mathrm{O} 2 / \mathrm{O}^{\mathrm{iv}} / \mathrm{O} 4^{\mathrm{i}} / \mathrm{O} 5$ forming the square faces: the dihedral angle between them is $3.04(6)^{\circ}$. Pr1 lies roughly equidistant from the square faces, by -1.2280(9) $\AA$ from the first and 1.2723(9) $\AA$ from the second. The capping $\mathrm{O} 1$ and $\mathrm{O} 4{ }^{\text {iii }}$ atoms display the two longest $\mathrm{Pr}-\mathrm{O}$ bond distances (Table 3 ) and the $\mathrm{O} 1-\mathrm{Pr} 1-\mathrm{O} 4^{\mathrm{iii}}$ bond angle is $174.98(5)^{\circ}$.

The glu $^{2-}$ and $\mathrm{Hglu}^{-}$species in 2 have different conformations: the $\mathrm{C} 1$ (glutarate) dianion is in an extended conformation, whereas the $\mathrm{C} 6$ (hydrogen glutarate) anion is twisted, with the $\mathrm{C}-\mathrm{C}-\mathrm{C}-\mathrm{C}$

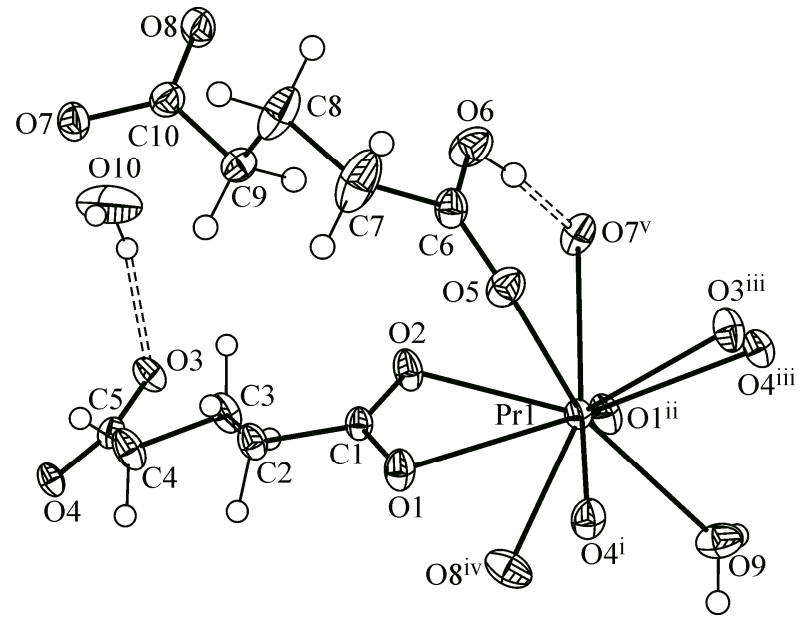

Fig. 4. Asymmetric unit of 2 (50\% displacement ellipsoids) expanded to show the complete metal coordination sphere. The hydrogen bonds are shown as doubledashed lines. Symmetry codes as in Table 3

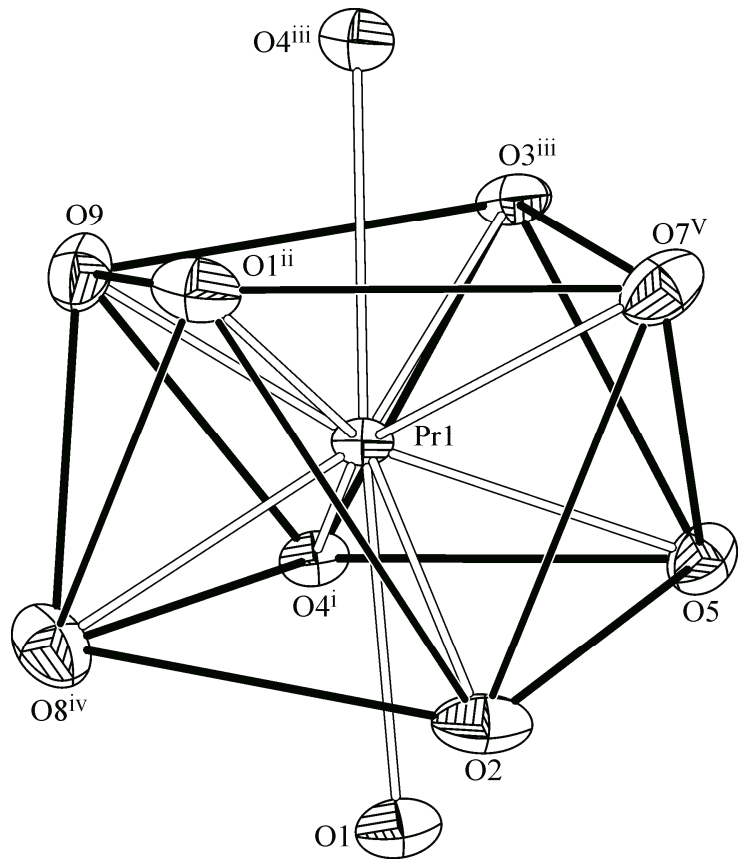

Fig. 5. Pr coordination sphere in $\mathbf{2}$. Symmetry codes as in Table 3 
Selected bond lengths $(\AA)$ and angles (deg.) for 2

\begin{tabular}{|c|c|c|c|c|c|c|c|c|}
\hline $\operatorname{Pr} 1-O 4^{i}$ & $2.4377(17)$ & \multicolumn{2}{|c|}{$\operatorname{Pr} 1-O 1^{i i}$} & \multicolumn{2}{|c|}{$2.4416(17)$} & \multicolumn{2}{|c|}{$\mathrm{C} 1-\mathrm{C} 2-\mathrm{C} 3-\mathrm{C} 4$} & $169.1(2)$ \\
\hline $\operatorname{Pr} 1-\mathrm{O} 3^{\mathrm{iii}}$ & $2.5289(17)$ & \multicolumn{2}{|c|}{$\operatorname{Pr} 1-08^{\mathrm{iv}}$} & \multicolumn{2}{|c|}{$2.5444(18)$} & \multicolumn{2}{|c|}{$\mathrm{C} 6-\mathrm{C} 7-\mathrm{C} 8-\mathrm{C} 9$} & 61.1(4) \\
\hline $\mathrm{Pr} 1-\mathrm{O} 2$ & $2.5482(18)$ & \multicolumn{2}{|c|}{$\operatorname{Pr} 1-09$} & \multicolumn{2}{|c|}{$2.5509(18)$} & \multicolumn{2}{|c|}{$\mathrm{C} 2-\mathrm{C} 3-\mathrm{C} 4-\mathrm{C} 5$} & $-173.5(2)$ \\
\hline $\operatorname{Pr} 1-\mathrm{O}^{\mathrm{v}}$ & $2.6536(19)$ & \multicolumn{2}{|c|}{ Pr1-O5 } & \multicolumn{2}{|c|}{$2.6554(18)$} & \multicolumn{2}{|c|}{$\mathrm{C} 7-\mathrm{C} 8-\mathrm{C} 9-\mathrm{C} 10$} & $179.3(2)$ \\
\hline $\operatorname{Pr} 1-\mathrm{O} 1$ & $2.6946(18)$ & \multicolumn{2}{|c|}{$\operatorname{Pr} 1-\mathrm{O} 4^{\mathrm{iii}}$} & \multicolumn{2}{|c|}{$2.7508(18)$} & & & \\
\hline $\mathrm{C} 1-\mathrm{O} 2$ & $1.250(3)$ & \multicolumn{2}{|c|}{$\mathrm{C} 1-\mathrm{O} 1$} & \multicolumn{2}{|c|}{$1.277(3)$} & & & \\
\hline $\mathrm{C} 5-\mathrm{O} 3$ & $1.258(3)$ & \multicolumn{2}{|c|}{$\mathrm{C} 5-\mathrm{O} 4$} & \multicolumn{2}{|c|}{$1.272(3)$} & & & \\
\hline $\mathrm{C} 6-\mathrm{O} 5$ & $1.244(3)$ & \multicolumn{2}{|c|}{$\mathrm{C} 6-\mathrm{O} 6$} & \multicolumn{2}{|c|}{$1.282(3)$} & & & \\
\hline $\mathrm{C} 10-\mathrm{O} 8$ & $1.230(3)$ & \multicolumn{2}{|c|}{$\mathrm{C} 10-\mathrm{O} 7$} & \multicolumn{2}{|c|}{$1.294(3)$} & & & \\
\hline & \multicolumn{2}{|c|}{$\mathrm{O} 6-\mathrm{H} 1 \cdots \mathrm{O} 7^{\mathrm{v}}$} & \multicolumn{2}{|c|}{$78(3)$} & $1.69(4)$ & $2.464(3)$ & $173(4)$ & \\
\hline & \multicolumn{2}{|c|}{$\mathrm{O} 9-\mathrm{H} 2 \cdots \mathrm{O} 5^{\mathrm{ii}}$} & 0.82 & 82 & 2.02 & $2.833(3)$ & 175 & \\
\hline & \multicolumn{2}{|c|}{$\mathrm{O} 9-\mathrm{H} 3 \cdots \mathrm{O} 10^{\mathrm{iv}}$} & \multicolumn{2}{|c|}{0.82} & 1.95 & $2.760(3)$ & 175 & \\
\hline & \multicolumn{2}{|c|}{$\mathrm{O} 10-\mathrm{H} 4 \cdots \mathrm{O} 3$} & \multicolumn{2}{|c|}{0.81} & 2.06 & $2.851(3)$ & 163 & \\
\hline & \multicolumn{2}{|c|}{$\mathrm{O} 10-\mathrm{H} 5 \cdots \mathrm{O} 7$} & 0.81 & & 2.52 & $3.166(3)$ & 138 & \\
\hline
\end{tabular}

For the hydrogen bonds, the four values correspond to the $D-\mathrm{H}, \mathrm{H} \cdots A$ and $D \cdots A$ separations $(\AA)$ and the $D-\mathrm{H} \cdots A$ angle (deg), respectively.

Symmetry codes: ${ }^{\mathrm{i}} 3 / 2-x, 1-y, z-1 / 2 ;{ }^{\text {ii }} 3 / 2-x, y-1 / 2, z ;{ }^{\text {iii }} x, 1 / 2-y, z-1 / 2 ;{ }^{\text {iv }} x+1 / 2, y$, $1 / 2-z ;{ }^{\mathrm{v}} 1-x, y-1 / 2,1 / 2-z$.

part of the chain incorporating the carboxylic acid group gauche and the equivalent grouping incorporating the carboxylate group anti (Table 3). The dihedral angle between the $\mathrm{C} 1 / \mathrm{O} 1 / \mathrm{O} 2$ and $\mathrm{C} 5 / \mathrm{O} / 3 \mathrm{O} 4$ planes is $31.69(18)^{\circ}$; that between the $\mathrm{C} 6 / 05 / 06$ and $\mathrm{C} 10 / 07 / 08$ planes is $39.1(4)^{\circ}$.

The bonding modes of the ligands in $\mathbf{2}$ are quite different: the $\mathrm{C} 1$ species is bridging bidentate $\left(\mathrm{O}, \mu^{2}-\mathrm{O}^{\prime}\right)$ from both its carboxylate groups, whereas the $\mathrm{C} 6$ species is simple monodentate from its $-\mathrm{CO}_{2} \mathrm{H}$ group and bridging monodentate from its $-\mathrm{CO}_{2}^{-}$group. In the $\mathrm{C} 1$ species, the metal ions are displaced by $0.477(11) \AA$ and $0.401(11) \AA$ from their chelating $\mathrm{C} 1$ and $\mathrm{C} 5$ groups respectively.

The $\mathrm{C}-\mathrm{O}$ bond lengths in the ligands in 2 are of some interest: for the $\mathrm{C} 1$ group of the glutarate ion, the $\mu^{2}-\mathrm{O}$ atom has the longer $\mathrm{C}-\mathrm{O}$ bond (by about $0.027 \AA$ ), which is equivalent to the situation in compound 1 , but for the $\mathrm{C} 5$ group, the $\mu^{2}-\mathrm{O}$ atom actually has the slightly shorter $\mathrm{C}-\mathrm{O}$ bond, by some $0.014 \AA$. In the hydrogen glutarate ion, the difference between the nominal $\mathrm{C} 6=\mathrm{O} 5$ double-bond and $\mathrm{C} 6-\mathrm{O} 6 \mathrm{H}$ single-bond is $0.038 \AA$, which is considerably less than the mean value of $0.094 \AA$ from a survey of carboxylic acid structures in the literature [19]. Finally, in the $\mathrm{C} 10$ grouping, the $\mathrm{C}-\mathrm{O}$ bonds show the greatest difference in length, of some $0.064 \AA$, despite their $\mathrm{O}$ atoms having the same bonding modes! The last of these may in part be explained by the fact that $\mathrm{O} 7$ accepts a short and (presumably) strong $\mathrm{O}-\mathrm{H} \cdots \mathrm{O}$ hydrogen bond from the $\mathrm{C}-\mathrm{OH}$ group, with $\mathrm{O} \cdots \mathrm{O}=2.464(3) \AA$.

In the crystal of 2 , the $\mathrm{PrO}_{10}$ polyhedra share an edge (via $\left.\mathrm{O}^{\mathrm{i}} \cdots \mathrm{O} 4^{\mathrm{iii}}\right)$ to generate [010] chains (Fig. 6) with $\operatorname{Pr} 1 \cdots \operatorname{Pr} 1^{\mathrm{vi}}(\mathrm{vi}=3 / 2-x, y-1 / 2, z)=4.3800(3) \AA$. The bridging ligands link the [010] chains into a three-dimensional coordination network incorporating small [010] channels which are occupied by the O10-water molecules (Fig. 6).

\section{DISCUSSION}

So far as we can ascertain, the one-dimensional polymeric crystal structure of $\mathbf{1}$ is a new structure type. A closely related compound is $\left[\mathrm{Nd}\left(\mathrm{C}_{5} \mathrm{H}_{6} \mathrm{O}_{4}\right)\left(\mathrm{H}_{2} \mathrm{O}\right)_{4}\right] \cdot \mathrm{Cl} \cdot 2 \mathrm{H}_{2} \mathrm{O}[20]$, in which essentially the same polymeric chains as seen in $\mathbf{1}$ incorporate both chloride ions and two uncoordinated water molecules per formula unit into the inter-chain voids. 


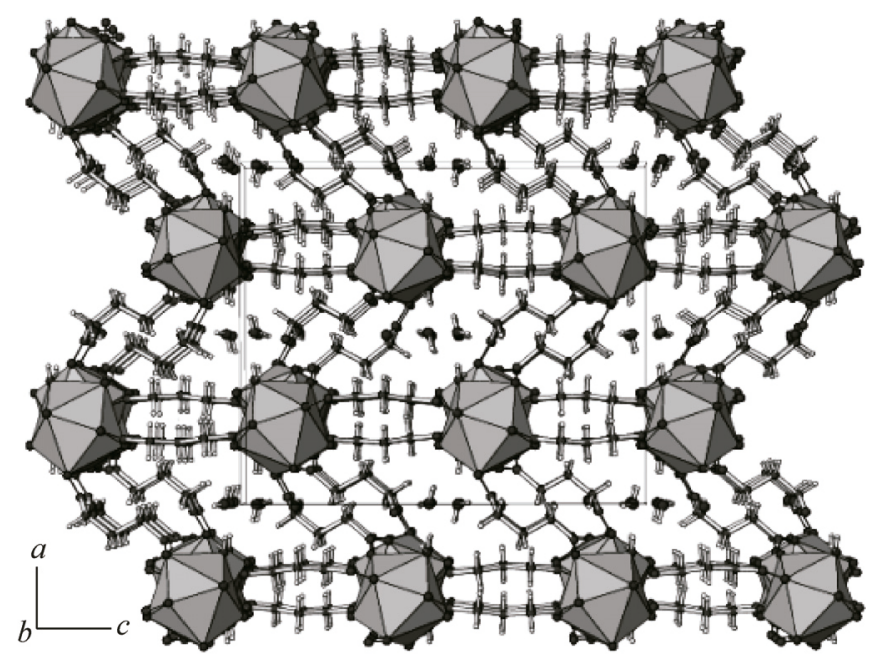

Fig. 6. Unit-cell packing for 2 viewed down [010] showing the small channels occupied by water molecules. The face-sharing $\mathrm{PrO}_{10}$ polyhedral chains propagate along [010]

Compound 2 is isostructural with its lanthanum congener [21], in which the mean La-O distance is $2.624 \AA$, which is the expected trend based on the lanthanide contraction effect [22 ].

Our survey of 49 rare-earth-glutarate crystal structures (including series of isostructural compounds) in the Cambridge Database (version 5.34 with two updates) revealed that 29 glutarate ions adopt a gauche-anti conformation [23 ] (i.e. the modulus of one $\mathrm{C}-\mathrm{C}-\mathrm{C}-\mathrm{C}$ torsion angle lies in the range $\sim 55-70^{\circ}$ and the other is greater than $\sim 160^{\circ}$ ), 17 have an anti-anti conformation, and just one $\left[\operatorname{Pr}\left(\mathrm{C}_{5} \mathrm{H}_{6} \mathrm{O}_{4}\right)\left(\mathrm{H}_{2} \mathrm{O}\right)_{2} \mathrm{Cl}\right]_{n}$ [24] has a gauche-gauche conformation. Two isostructural compounds $\left[\mathrm{M}_{2}\left(\mathrm{C}_{8} \mathrm{H}_{4} \mathrm{O}_{4}\right)\left(\mathrm{C}_{5} \mathrm{H}_{4} \mathrm{O}_{4}\right)_{2}\left(\mathrm{H}_{2} \mathrm{O}\right)_{2}\right]_{n}\left(\mathrm{M}=\mathrm{Dy}, \mathrm{Sm} ; \mathrm{C}_{8} \mathrm{H}_{4} \mathrm{O}_{4}=\right.$ benzene 1,3-dicarboxylate $)$ [25] could not be classified, with one gauche torsion angle and one of about $120^{\circ}$, which corresponds to an eclipsed conformation.

\section{CONCLUSIONS}

The new rare-earth glutarates $\left[\mathrm{Nd}\left(\mathrm{C}_{5} \mathrm{H}_{6} \mathrm{O}_{4}\right)\left(\mathrm{H}_{2} \mathrm{O}\right)_{4}\right] \cdot \mathrm{Cl}(\mathbf{1})$ and $\left[\mathrm{Pr}\left(\mathrm{C}_{5} \mathrm{H}_{6} \mathrm{O}_{4}\right)\left(\mathrm{C}_{5} \mathrm{H}_{7} \mathrm{O}_{4}\right)\left(\mathrm{H}_{2} \mathrm{O}\right)\right] \cdot \mathrm{H}_{2} \mathrm{O}$ (2) have been prepared in the form of single crystals and their structures were determined. Compound 1 is a new structure type, although it is closely related to a compound that also contains uncoordinated water molecules. Compound $\mathbf{2}$ is isostructural with its lanthanum analogue and its mean metal-ligand bond length follows the expected trend of the lanthanide contraction.

We are thankful to the Higher Education Commission of Pakistan for providing the financial support to this project.

\section{REFERENCES}

1. Wyatt V.C. // J. Appl. Polymer Sci. - 2012. - 126. - P. 1784 - 1793.

2. Gopunath A.G., Chitravel T., Kavitha C., Prabu N.P.S., Mohan M.L.N.M. // Molec. Crys. Liq. Crys. - 2013. -574. - P. $19-32$.

3. Gou L., Han Z.X., Hu H.M., Wu Q.R., Yang X.L., Yang Z.H., Wang B.C., Wang F., Yang M.L., Xue G.L. // Inorg. Chim. Acta. - 2010. - 363. - P. 2590 - 2599.

4. Duangthongyou T., Phakawatchai C., Siripaisarnpipat S. // J. Mol. Struct. - 2011. - 987. - P. $101-105$.

5. Zhen Y.Q., Zhu H.L., Guo X.X., Liu J.Y. // Solid State Sci. - 2013. - 18. - P. 42 - 49.

6. Rahahalia N., Benmerad B., Guehria-Laidouadi A., Dahaoui S., Lecomte C. // Acta Crystallogr. - 2006. - E62. - P. m2147- m2147.

7. Wang Z., Bai F.Y., Xing Y.H., Xie Y., Zeng X.Q., Ge M.F., Niu S.Y. // J. Inorg. Organomet. Poly Mat. - 2010. - 20. - P. $242-249$.

8. Wang C.G., Xing Y.H., Li Z.P., Li J., Zeng X.Q., Ge M.F., Niu S.Y. // J. Mol. Struct. - 2009. - 931. - P. 76 - 81. 
9. Sheldrick G.M. SADABS. University of Gottingen, Germany, 2007.

10. Sheldrick G.M. // Acta Crystallogr. - 2008. - A64. - P. 112 - 122.

11. Farrugia L.J. // J. Appl. Cryst. - 1997. - 30. - P. 565.

12. ATOMS for Windows., version 6.3. Shape Software Inc., Kingsport, Tennessee, USA.

13. Cheyne R.W., Smith T.A.D., Trembleau L., Mclaughlin A.C. // Nanoscale Res. Lett. - 2011. - 6. - P. article 423; DOI 10.1186/1556-276X-6-423.

14. Singh G.S., Pheko T. // Spectrochim. Acta. - 2008. - A70. - P. $595-600$.

15. Brown I.D., Altermatt D. // Acta Crystallogr. - 1985. - B41. - P. $244-247$.

16. Yin W.Y., Tang X.Y., Yang J., Ma Y.S., Yuan R.X. // J. Coord. Chem. - 2010. - 63. - P. $1157-1164$.

17. Allen F.H., Motherwell W.D.S. // Acta Crystallogr. - 2002. - 58. - P. $407-422$.

18. Yang Y.Q., Li C.H., Li W., Yi Z.J. // Chin. J. Chem. - 2010. - 28. - P. $1385-1388$.

19. Allen F.H., Kennard O., Watson D.G., Brammer L., Orpen A.G., Taylor R. // J. Chem. Soc. Perkin Trans. 2. - 1987. - P. S1 - S19.

20. Legendziewicz J., Keller B., Turowska-Tyrk I., Wojciechowski W. // New J. Chem. - 1999. - 23. - P. 1097 1103; Marsh RE. // Acta Crystallogr. - 2005. - B61. - P. 359.

21. Benmerad B., Guehria-Laidoudi A., Balegroune F., Birkedal H., Chapuis G. // Acta Crystallogr. - 2000. - C56. - P. 789 - 792.

22. Gu J.Z., Wu J., Lv D.Y., Tang Y., Zhu K., Wu J. // Dalton Trans. - 2013. - P. 4822 - 4830.

23. Rather B., Zaworotko M.J. // Chem. Commun. - 2003. - P. 830 - 831.

24. Bromant C., Nika W., Pantenburg I., Meyer G. // Zeit. Anorg. Allg. Chem. - 2005. - 631. - P. 2416 - 2422.

25. Hu D.-X., Luo F., Che Y.-X., Zheng J.-M. // Cryst. Growth Des. - 2007. - 7. - P. 1733 - 1737. 